\title{
INFORMATION SOURCES AFFECTING CONSUMER BEHAVIOUR IN THE ELECTRICITY MARKET
}

\author{
Marzena Czarnecka \\ University of Economics Katowice, Katowice, Poland \\ e-mail: marzena.czarnecka@ue.katowice.pl \\ (C) 2018 Marzena Czarnecka \\ This is an open access article distributed under the Creative Commons Attribution-NonCommercial-NoDerivs license \\ (http://creativecommons.org/licenses/by-nc-nd/3.0/) \\ DOI: $10.15611 / \mathrm{ms} .2018 .2 .01$ \\ JEL Classification: M31, P18, P46, R2
}

\begin{abstract}
Electricity is a factor that facilitates the functioning of consumers in society and creates appropriate conditions for work, development and rest. Due to the scale and pace of the changes resulting from technological progress and new regulations, consumers in the electricity market do not have the appropriate technical, economic or legal knowledge. The most significant problems within the electricity market in Poland include the high level of ignorance of the services, institutions and basic terms required for making rational decisions in the electricity market. This is necessary in order to determine the sources from which consumers derive knowledge about the electricity market. Based on the research carried out by the author, it can be argued that the knowledge and skills concerning an evaluation of the electricity market, the institutions operating therein and their product are very low.
\end{abstract}

Keywords: consumer behaviour in the electricity market, electricity, consumers.

\section{Introduction}

Electricity is a factor that facilitates the functioning of consumers in society and creates the appropriate conditions for work, development and rest. Due to the scale and pace of the changes resulting from technological progress and new regulations, consumers in the electricity market do not have the appropriate technical, economic or legal knowledge. The most significant problems within the electricity market in Poland include the high level of ignorance of the services, institutions and the basic terms required for making rational decisions in the electricity market. According to the European Commission's DG Sanco, such a consumer may be regarded as an "energy illiterate", who does not have:

- the knowledge and skills to be able to evaluate the energy service market,

- the ability to identify the possibility of help in energy related cases,

- the ability to take effective measures aimed at protecting their own interests [DG Sanco 2010].
The consumer is the weaker party in the transaction and requires both legal and institutional information and - above all - educational support. Therefore, it is necessary to determine the sources from which consumers derive their knowledge about the electricity market and whether such information is presented to the average consumer in a digestible, legible and comprehensible manner.

To accomplish this goal, the analysis covered the relevant literature as well as the available websites and Internet resources regarding the examined phenomenon. To illustrate these issues, the results of the empirical research carried out on a group of 1,109 people were used. The research was carried out in February 2017 and concerned consumer behaviour in the electricity market. It examined, among other issues, whether consumers read information materials and leaflets concerning electricity. The examined sample was representative, while the selection of people for the sample was random. The variables were gender, age, education, number of household members, occupation, type of building where the household is located, income and class of town size in 
accordance with the distribution of Central Statistical Office of Poland (GUS).

\section{Consumers in the electricity market}

The energy market is one sector where the relationship between the consumer and the service provider is very asymmetrical. On one side are large companies, which have professional knowledge and specialists (in the field of energy and also advertisment, marketing and law), while on the other side are the consumers, whose knowledge and capabilities are considerably lower. Although consumer rights in the telecommunication and financial sectors have a long history and tradition, the energy market has still been focused on infrastructure and is only now discovering the customer as its partner and stakeholder [Pluskwa-Dąbrowski 2016]. The legislator does not use the specific term "consumer" for the purposes of Energy Law; instead, the terms defined therein are "recipient" and "recipient in a household". These terms have also not been strictly defined in European Union law (more: [Gnela (ed.) 2007; Frąckowiak, Stefanicki (eds) 2011; Jagielska, Rott-Pietrzyk, Wiewiórkowska-Domagalska (eds) 2012]). However, it may be assumed that the terms "consumer" and "recipient in a household" have an identical meaning. In addition, Article 2 par. 8 of the Act on Combating Unfair Market Practices [Act of 23 August 2007] defines the term "average consumer" as someone who is a sufficiently informed, careful and cautious; this assessment is made taking into account social, cultural and linguistic factors and the membership of a given consumer of a special group of consumers. This is understood as a clearly identifiable group of consumers that is particularly susceptible to the impact of market practices or the product affected by market practices, due to characteristics such as age or physical or mental disabilities more in: [Michalak 2008; Stefanicki 2009; Sieradzka 2008; Zdyb, Sieradzka (eds) 2016; Sieradzka 2014]. The assumed model of an average consumer is a careful, sensible and critical person. An average consumer is capable of reading the information addressed to $\mathrm{him} / \mathrm{her}$ and displays a certain degree of criticism ${ }^{1}$. In addition, such a consumer has a certain pool of information, a certain level of market awareness and can make use of that by analysing market messages. A model consumer will always be characterised by the aforementioned traits, which will be present to varying degrees. The consumer's care level, in turn, can be lower, depending on which goods the relevant advertisement refers to and in what circumstances they are purchased. It must be remembered that the model of an average consumer, who is duly informed, careful and sensible, must not be defined in isolation from the conditions of supply and the realities of economic life, which are determined separately in each case ${ }^{2}$. In many situations, the legislator puts the consumers in a privileged position and stipulates numerous legal remedies for them. Such protection results from the potential inequality of participants in the civil law context, i.e., professionals (service providers) who are economically and organisationally stronger and structurally weaker entities that have a considerably smaller range of information at their disposal (consumers) [Królikowska-Olczak, Pachuca-Smulska (eds) 2013]. Although the equal status of the parties in a civil law relationship is a fundamental principle of civil law, in the author's opinion, in practice and in the wording of the provisions of the law, this principle does not work in the electricity market, where the consumer is in a privileged position, in accordance with EU regulations. Many recipients still treat their energy company as an official authority, which is confirmed by the documents enclosed detailing complaints received by the Federation of Consumers. Instead of "complaints", consumers often write "applications", and, while in a dispute with an energy company, they seek help from administrative proceedings, official authorities as well as consumer organisations [Pluskwa-Dąbrowski 2016].

The structure of the energy market, which was established by a horizontal division into generation, transmission, distribution and sales, is completely illegible to consumers. This is proven, for example, by the small percentage of households that change their electricity provider. This is likely also caused by the affiliation of companies from all links of the chain, from production to sales, within a single capital group; it becomes quite difficult for the consumer to distinguish a distribution company from a sales company when their names and logos are nearly identical. The current status quo contributes to the lack of transparency and the difficulties in determining who is who in the electricity market [Pluskwa-Dąbrowski 2016].

\footnotetext{
${ }^{1}$ The term "average consumer" was used by the Court for the first time in the Commission v Germany judgment (ECJ judgment of 22.5.1992 in C-290/90, ECLI:EU:C:1992:227, Commission v Germany, ECR 1992, p. I-3874).

2 Judgment of the Administrative Court in Warsaw of 29.9.2011, VI ACa 747/11, Legalis.
} 


\section{Consumer awareness in the Polish electricity market}

Consumer awareness, which refers also on the electricity market to a buyer's knowledge of a particular product or company, allows the buyer to get the most from what he/she buys. Consumers can make wellinformed choices about what to buy and how much to spend when they have product information. Consumers benefit from knowing their rights and reviewing alerts and warnings. [Straatmann, Lin-Hi, Muller 2016] Electricity consumers in Poland are not a homogeneous group in terms of degree of awareness. Obviously, the "average" consumer could be proposed, but this would be an oversimplification. Three primary groups were distinguished during the research conducted by the Federation of Consumers: "prosumers, aware consumers and (passive) consumers". This distinction was based not only on the level of knowledge but also on the commitment and activity on the part of energy recipients. Prosumers are interested in an active, participatory model of their presence in the electricity market. If it is physically possible and if the premises are available, they would consider obtaining their own micro-installation. They decide to use energy-efficient household appliances more often than others. Aware consumers are not active or committed but are aware (at least generally) of their rights and are ready to search for knowledge if necessary. Aware consumers are usually guided by a pragmatic approach; they know that there are certain possibilities to act but take measures only if they see specific benefits, which are mainly - but not exclusively - financial. This group is growing (at the expense of passive consumers) and it can be expected that, in the future, they will evolve into prosumers. However, for this to occur, a new market model and the introduction of technologies must take into account the end consumer's interest. Passive consumers are recipients who are not interested in their rights or possibilities to act (e.g., energy saving, seller choice, tariff change, etc.), at least as long as the irregularities do not affect them. If there is a dispute with an energy company, passive consumers do not decide to exercise their rights because, subconsciously,

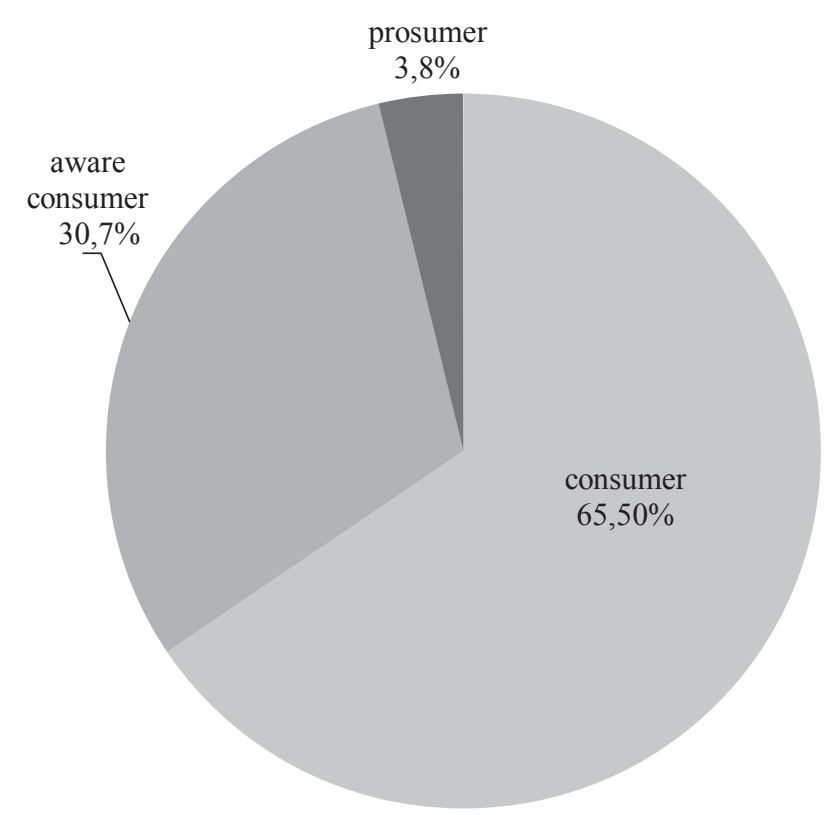

Fig. 1. Consumer awareness

Source: Research by the Federation of Consumers, p. 3 [Pluskwa-Dąbrowski 2016].

they are convinced that "it's impossible to win against such a big company" [Pluskwa-Dąbrowski 2016].

The current state of knowledge of the Polish consumer (and individual groups described above) can be demonstrated by the results of research conducted by the Consumer Federation in July 2015 on a group of 1200 respondents using the PAPI method ${ }^{3}$. This data is comparable with European findings. Across the EU28, 26\% of the survey respondents rejected the statement that the retail electricity market in their country was not functioning very well as opposed to $23 \%$ who "strongly agreed_" with this statement and expressed doubts about the existence of a wellfunctioning market in their country. Respondents in the consumer survey were asked whether they felt informed about various aspects of their household's electricity use. The data is presented below ${ }^{4}$.

\footnotetext{
${ }^{3}$ The data and charts are derived from the FK study, available at: http://www.federacja-konsumentow.org.pl/prosument/images/ grafiki/pdf/RaportOZE.pdf

${ }^{4}$ The research questions on the functioning of the retail markets focused on the regulatory environment, available choice, comparability, bills, prices, affordability, availability and quality of information, quality of service, complaint handling, sustainable use of energy and innovation. The research questions on consumer participation in the electricity market focused on general consumer attitudes and expectations, consumer awareness, consumer engagement with the market, and consumer mobility, consumer experiences, problems and complaints. The objective of the consumer survey was to get insights in consumers' awareness, attitudes and experiences with electricity services. The consumer survey was designed to target members of the general population (aged 18+), who are fully or jointly in charge of paying the electricity bill in their household. In total, 29,119 interviews were conducted across 30 countries (EU28, Iceland and Norway). The detailed methodology for the consumer survey is presented in [www 3].
} 
Strongly agree (8 to 10$) \square$ Agree (5 to 7) Disagree (0 to 4) Don't know

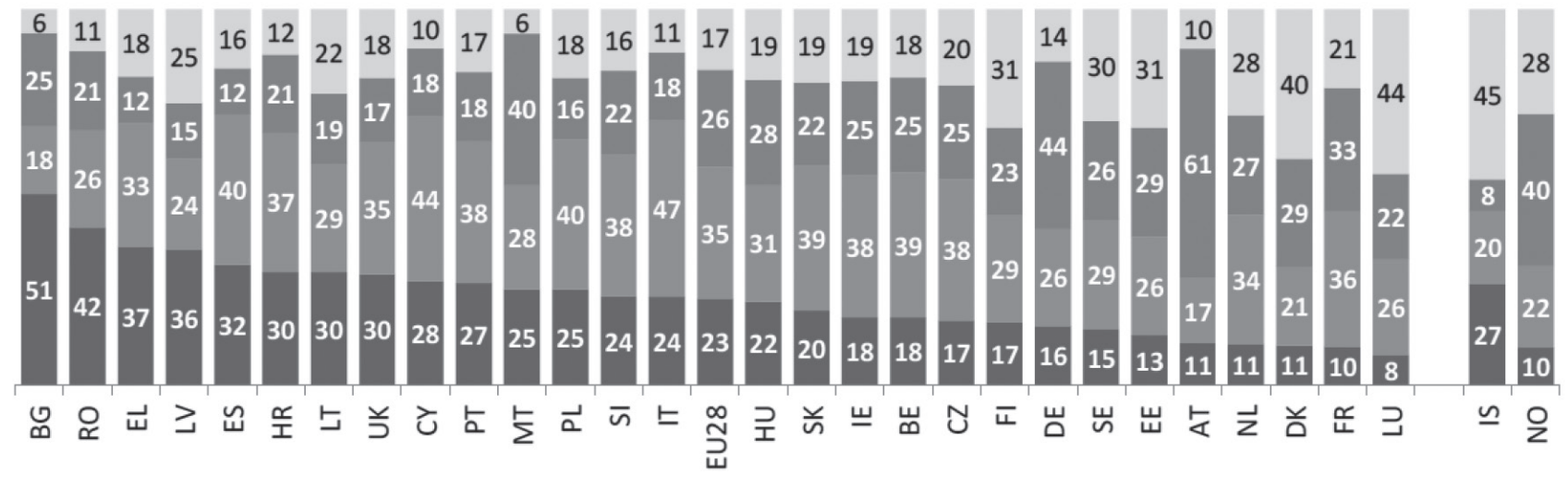

Question: Please indicate how much you agree or disagree with the following statement, using a scale from 0 to 10 , where 0 means that you "totally disagree" and 10 means "totally agree" The retail electricity market in you country is not functioning very well. $\%$ by country.

Fig. 2. Answers of respondents who rejected the statement that the retail electricity market in their country was not functioning very well

Source: [www 3].

\section{Access to knowledge and information about rights}

Consumers who are interested in accessing knowledge and information are able to do so. The activities of the public sector, including in particular the Energy Regulatory Office (URE), have recently been quite strongly oriented towards consumer protection. Pursuant to Article 5 par. 6e of the Energy Law [Act of 10 April 1997], sellers are obliged to supply a copy of the set of consumer rights, which is supposed to constitute a package of practical information about the rights of recipients in a household. This document is too extensive and seems overly complex for the average consumer. The set of rights of energy consumers is prepared by the President of the URE in cooperation with the President of the Office of Competition and Consumer Protection (UOKiK), based on the European Commission's guidelines and in consultation with the national regulatory authorities, consumer organisations, social partners, energy companies and other interested parties. Under Article 5 par. $6 \mathrm{f}$ of the Energy Law, the copy of the set of rights of energy consumers referred to in Article $6 \mathrm{e}$ of that law is pronounced by the President of the URE in the URE's Public Information Bulletin (BIP). Unfortunately, consumers in Poland do not know what the set of consumer rights is or that this document defines their rights and obligations. The greatest percentage of people who are unaware of the existence of this set are those with basic education
(55.5\%) and those who are temporarily unemployed, on parental leave or on long-term sick leave (54.5\%). People under 25 are characterised by the highest awareness $(37.2 \%$ of them know what the set of consumer rights is).

Table 1. Consumer awareness of the set of consumer rights concerning electricity

\begin{tabular}{|l|l|c|c|c|c|}
\hline \multicolumn{2}{|c|}{ Do you know what the set of consumer rights concerning electricity is? } \\
\hline \multicolumn{2}{|c|}{} & Frequency & Percentage & $\begin{array}{c}\text { Percentage } \\
\text { of valid } \\
\text { respondents }\end{array}$ & $\begin{array}{l}\text { Cumulative } \\
\text { percentage }\end{array}$ \\
\hline Valid & Yes & 305 & 27.5 & 27.5 & 27.5 \\
\cline { 2 - 6 } & No & 471 & 42.5 & 42.5 & 70.0 \\
\cline { 2 - 6 } & $\begin{array}{l}\text { I've } \\
\text { heard } \\
\text { the } \\
\text { name, } \\
\text { but } \\
\text { I don't } \\
\text { know } \\
\text { what it } \\
\text { refers to }\end{array}$ & 333 & 30.0 & 30.0 & 100.0 \\
\hline & $\begin{array}{l}\text { Total } \\
\text { Totaly }\end{array}$ & 1109 & 100.0 & 100.0 & \\
\hline
\end{tabular}

Source: own research.

If the above obligations are not fulfilled, the President of UOKiK may find a violation of the collective interests of consumers, which consists of the violation of the obligation of energy companies to provide accurate, true and full information to consumers (Article 24 par. 2 subpar. 2 of the Act 
on Competition and Consumer Protection [Act of 16 February 2007]). Consumers are entitled to such information because these are extremely complex issues, especially as far as technical information is concerned [Cseres 2006].

Consumers in the electricity market find themselves in an involuntary and often ambiguous situation, and, due to the specificity of the electricity market, they have neither sufficient economic [Kieżel (ed.) 2015] nor specialist knowledge. In addition, they lack sufficient experience and are therefore often unprepared for the full freedom of choice the market provides. Furthermore, many do not always know how to assert possible claims when their interests are violated because they do not have the technical, economic or legal knowledge and market experience that electricity providers have [Kieżel (ed.)]. Nevertheless, consumers can make their market choices with full sovereignty and independence. Thanks to the liberalisation of the electricity market in the European Union, consumers are free to shape consumption structure and perceive and respond to marketing signals. Research carried out in the United States of America shows that consumers have quite well-developed cognitive abilities that lead to the recognition of various marketing instruments that may manipulate their decisions [Evans, Foxall, Jamal 2009]. However, it should be remembered that the creation of consumer behaviour through marketing activities must not be manipulative. If the shaping of sovereign consumer decisions is to occur, the resulting decisions must be based on reliable and indepth knowledge gained through consumer education [Dąbrowska, Janoś-Kresło, Ozimek 2005].

As shown by the results of the research carried out by the author, consumers do not read agreements and do not familiarise themselves with the information found in materials and leaflets. Therefore, it can be stated that messages from sellers constitute the sole source of information about the electricity market for consumers. The latter are free to make independent choices in the market, but, in order to make the right decisions that fulfil their expectations, they have to learn about the new market and obtain the necessary information. Thus, they are entitled to choose their electricity provider in a conscious and sensible manner. The problem is not the total lack of information but rather an excess of information; the obstacle consumers subsequently face is determining which information might prove useful. To a large extent, consumers combine and compare information from different sources while searching for information that is relevant to them. The intensity and scale of such information searches depend on the stimulus force (i.e. how much the information is needed to satisfy their needs), the ease of obtaining the information, its significance, the satisfaction felt by the customer when searching for information and the number of available sources.

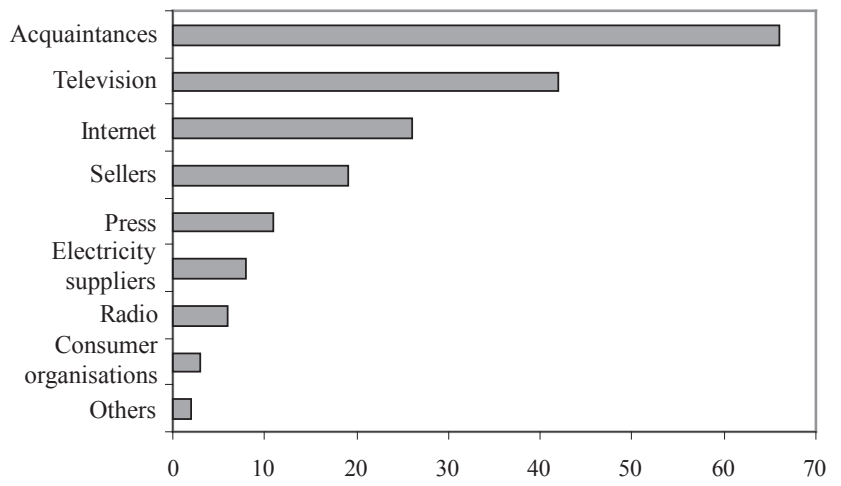

Fig. 3. Sources of information about the electricity market

Source: S. Smyczek, Edukacja rynkowa konsumentów na rynku energii elektrycznej, p. 8 [Czarnecka (ed.) 2014]5.

About $33 \%$ of the analysed consumers believe that sources of formal information, i.e. those delivered by electricity providers and energy company employees, are important, which means that it is particularly crucial for the company to meet statutory requirements. However, most say that such information is not conveyed in a clear and comprehensible manner. Leaflets and guidebooks are read the least frequently, since the majority of the examined consumers regard them as junk mail [Czarnecka (ed.) 2014].

This frequency analysis performed by the author, with a division into demographic questions, reveals that the manner of answering the question asked to the respondents is independent of their age, number of household members, gender, place of residence,

${ }^{5}$ Direct research was conducted using the questionnaire interview method in the Śląskie voivodeship in October 2012. In the selection of the sample, the purpose-based quantitative selection procedure was used. Based on the known structure of the surveyed population, the unit amounts, i.e. age and education level, were selected in relation to these features. The structure of the sample was selected so that it would be identical to the structure of the studied population in the Śląskie Voivodeship. Bearing in mind the advantages and disadvantages of individual sources of primary information, in order to collect, with limited resources, full and up-to-date information on the level of knowledge held by consumers on the electricity market and their behavior in this market, the direct questionnaire method was used . In the construction of the research tool itself (an interview questionnaire), techniques used in market and marketing research were used. After the tests, the collected data were subjected to control and systematization, which in turn enabled counting, a preliminary description of the collected data, as well as their qualitative and quantitative analysis. 562 questionnaires were qualified for further analyses. 
Table 2. The degree of familiarity with information materials and leaflets concerning electricity and additional services

To what extent do you agree with the statement: I read information materials and leaflets concerning electricity and additional services?

\begin{tabular}{|c|l|c|c|c|c|}
\hline \multicolumn{2}{|c|}{} & Frequency & Percentage & $\begin{array}{c}\text { Percentage of valid } \\
\text { respondents }\end{array}$ & $\begin{array}{c}\text { Cumulative } \\
\text { percentage }\end{array}$ \\
\hline \multirow{5}{*}{ Valid } & Strongly disagree & 367 & 33.1 & 33.1 & 33.1 \\
\cline { 2 - 6 } & Somewhat disagree & 294 & 26.5 & 26.5 & 59.6 \\
\cline { 2 - 6 } & No opinion & 259 & 23.4 & 23.4 & 83.0 \\
\cline { 2 - 6 } & Somewhat agree & 112 & 10.1 & 10.1 & 93.1 \\
\cline { 2 - 6 } & Strongly agree & 77 & 6.9 & 6.9 & 100.0 \\
\cline { 2 - 6 } & Total & 1109 & 100.0 & 100.0 & \\
\hline
\end{tabular}

Source: own research.

education, energy company with which the agreement is concluded, occupation and income.

The information reaching consumers can be divided according to various criteria. One of the primary classification methods is to allow for the source of a given piece of information. According to this criteria, market information can be divided into information coming from the electricity provider, from the authoritative institutions (in this case, the President of the URE or UOKiK), from independent sources (e.g. from consumer organisations, such as the Federation of Consumers), from interpersonal contacts (e.g. knowledge acquired from contacts among family and acquaintances) and from direct search and observation of the market and the offered product range. However, the latter is extremely difficult in the electricity market due to the specificity of this market. Information can be divided also into information from commercial (e.g. advertisements) and non-commercial (e.g. opinion-based) sources or into formal (e.g. conveyed by institutions or organisations) and informal (e.g. conveyed by friends, relatives or other customers) information [Garbarski 2001]. The information reaching the consumers can be impersonal (e.g. information conveyed by mass media) or personal (e.g. if its senders are specific people) [Schiffman, Kanuk 2014].

According to one of the broader functional classifications, information sources include: mass media, acquaintances and friends and other verbal contacts and commercial sources [Beatty, Farrell 1998]. Ph. Kotler divides information sources into personal (family, friends, acquaintances), commercial (advertisements, sellers), public (mass media, consumer organisations) and practical contact with the product offered (service, use) [Kotler, Keller 2015]. According to $S$. Gajewski, in turn, information sources can be divided into marketing (e.g. promotion, social media, websites), public (conveyed by mass media and consumer organisations) and personal (information from other people, e.g. acquaintances, relatives, friends and - in addition - sellers [Gajewski 1994]) sources.

The comprehensive classification of information sources is presented in Figure 4.

Identifying levels of satisfaction occurs only (or predominantly) in relation to internal sources of information (consumer experience) only in special circumstances. Individuals are willing to use such sources to a broader extent if they feel a high level of satisfaction with purchases made earlier, if the last purchase was made relatively recently or if the sales offer remains unchanged for a longer period [Garbarski, Rutkowski, Wrzosek 1997; Czarnecka (ed.) 2014].

In the majority of cases, consumers try to combine and compare information from various sources. On the one hand, a given person can be rather inactive, which is the case of the electricity market, and such behaviour is displayed by around $60 \%$ of respondents. On the other hand, consumer behaviour can be defined as an active search for information, when consumers take actions aimed at obtaining information on their own. Such behaviour in the electricity market is only characteristic of around 3\% of respondents [Czarnecka (ed.) 2014].

It seems that this situation is related to the market specificity. Consumers became accustomed to accessing electricity: "electricity is like air, consumers do not think about it, they just have it". In addition, they do not have the habit of searching for more favourable offers on the market than those proposed by their current sellers. Moreover, it is difficult to find such comparison engines that would help consumers compare the offered products. These issues were noticed by the European Commission, which, on 11 April 2018, presented a new order for consumers, the aim of which was to ensure that all 


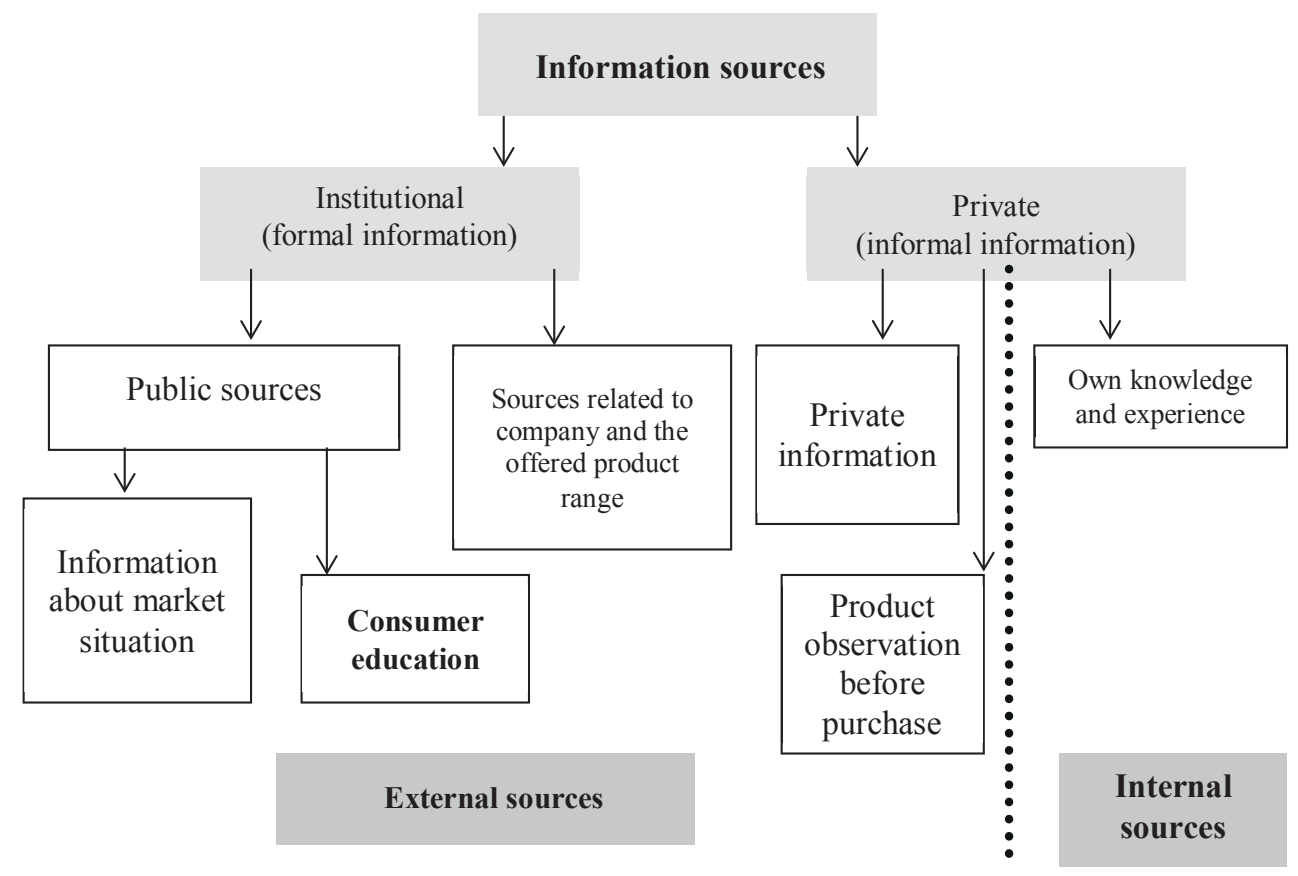

Fig. 4. Sources of market information for consumers

Source: [Gajewski 1994, p. 149].

European consumers could make full use of the rights they have under EU legislation. The new order for consumers will mean a reinforcement of consumer rights, in particular greater transparency related to search results on Internet platforms; consumers will be explicitly informed if the search result was paid by the service provider. Internet sales platforms will also have to inform consumers of the primary parameters specifying the ranking of results. There will be new consumer rights referring to "free" digital services: when paying for a digital service, consumers exercise certain rights to information and have 14 days to cancel the agreement (the right to revoke the agreement). In the new order, this right will also cover "free" digital services for which consumers provide their personal data [www 1].

\section{Conclusion}

There are 17.2 million recipients of electricity in Poland, the vast majority of which - as many as $\mathbf{1 5 . 6}$ million - are households. Annually, each consumes almost 2,200 kilowatt hours ( $\mathrm{kWh}$ ) of energy on average, paying around PLN 1.400 in total. According to GUS data, a typical electricity invoice amounts to nearly PLN 120 per month. Obviously, the majority of customers know that they can change the provider, i.e. use the offered product range. However, just over $4 \%$ of consumers use this privilege [www 2]. An impression can therefore be gained that the primary reason for this is the lack of information about the benefits of changing providers. Furthermore, consumers do not have full knowledge about the agreements concluded and the possibilities of choosing from the offered product range. The research carried out by the author reveals that consumer-education activities were not effective - the set of consumer rights fails to fulfil its function. In the author's opinion, consumer education should be introduced in schools to young people, who should become accustomed to searching for the right product in the electricity market. Currently when choosing among market offers consumers are guided by the opinions of their acquaintances, i.e. they use internal sources. Instead, they should be using external sources.

\section{Bibliography}

Beatty S.E., Farrell M.E., 1998, Impulse buying: modelling its precursors, Journal of Retailing, vol. 74, no 2

Cseres K.J., 2006, The impact of consumer protection on competition and competition law. the case of deregulated markets, ACWorkPaper, no 5, http://ssrn.com/paper=903284 (25.4.2017)

Czarnecka M. (ed.), 2014, Konsument na rynku energii elektrycznej. C.H.Beck, Warszawa.

Dąbrowska A., Janoś-Kresło M., Ozimek I., 2005, Ochrona i edukacja konsumentów we współczesnej gospodarce rynkowej, PWE - Polskie Wydawnictwo Ekonomiczne, Warszawa. 
DG Sanco, Consumers in Europe, http://epp.eurostat.ec.europa. eu/cache/ITY_OFFPUB/KS-DY-07-001/EN/KS-DY-07001-EN, z 17.10.2010 r. (27.04.2018).

Evans M., Foxall G., Jamal A., 2009, Consumer Behavior, Wiley, New York.

Frąckowiak J.R., Stefanicki R. (eds), 2011, Ochrona konsumenta w prawie polskim na tle koncepcji Effet Utile, Wydawnictwo Uniwersytetu Wrocławskiego, Wrocław, pp. 53-86.

Gajewski S., 1994, Zachowanie się konsumenta a współczesny marketing, Wydawnictwo Uniwersytetu Łódzkiego, Łódź.

Garbarski L., 2001, Zachowania nabywców, PWE - Polskie Wydawnictwo Ekonomiczne, Warszawa.

Garbarski L., Rutkowski I., Wrzosek W.,1997, Marketing. Punkt zwrotny nowoczesnej firmy, PWE - Polskie Wydawnictwo Ekonomiczne, Warszawa.

Gnela B. (ed.), 2007, Ochrona konsumenta ustug finansowych. Wybrane zagadnienia prawne, Wolters Kluwer Polska sp. z o.o., Kraków.

Jagielska M., Rott-Pietrzyk E., Wiewiórkowska-Domagalska A. (eds), 2012, Kierunki rozwoju europejskiego prawa prywatnego. Wplyw europejskiego prawa konsumenckiego na prawo krajowe, C.H.Beck, Warszawa, pp. 169-184.

Kieżel E., 2015, Wiedza ekonomiczna polskich konsumentów jako podstawa racjonalizacji zachowań, MiR, no 8.

Kieżel E. (ed.), 2007, Ochrona interesów konsumentów w Polsce $w$ aspekcie integracji europejskiej, Difin, Warszawa.

Kotler Ph., Keller K., 2015, Framework for Marketing Management, Pearsons, 15 th edition, New York.

Królikowska-Olczak M., Pachuca-Smulska B. (eds), 2013, Ochrona konsumenta w prawie polskim i Unii Europejskiej, C.H. Beck, Warszawa.

Michalak A., 2008, Komentarz Ustawa o przeciwdziałaniu nieuczciwym praktykom rynkowym, C.H.Beck, Warszawa.

Pluskwa-Dąbrowski K., 2016, Konsument w energetyce - rzut oka w przyszłość, www.documents.clientearth.org, p. 2, 3,4 (29.04.2018).
Schiffman L.G., Kanuk L.L., 2014, Consumer Behavior: Global Edition, Pearson, 11th edition, London.

Sieradzka M., 2008, Komentarz Ustawa o przeciwdziałaniu nieuczciwym praktykom rynkowym, Wolters Kluwer business Warszawa 2008, pp. 56 etc., 63 etc.

Sieradzka M., 2014, Wzorzec przeciętnego konsumenta jako punkt odniesienia przy dokonywaniu oceny nieuczciwości praktyki rynkowej. Glosa do wyr. SN z 4.3.2014 r., II SK 34/13, IKAR, nr 6(3).

Stefanicki R., 2009, Komentarz Ustawa o przeciwdziataniu nieuczciwym praktykom rynkowym, LexisNexis, Warszawa.

Straatmann T., Lin-Hi N., Muller K., 2016 Consumer awareness and sustainability-focused value orientation as motivating factors of responsible consumer behavior, Review of Managerial Science October 2017, vol. 11, Issue 4, pp. 959-991.

Ustawa z dnia 10 kwietnia 1997 r. Prawo energetyczne, t.j. 20.04.2018, Dz.U. 755 z 2018 r.

Ustawa z dnia 16 lutego 2007 r. o ochronie konkurencji i konsumentów, tj. 27.04 .2018 r., Dz.U. 798 z 2018 r.

Ustawa z dnia 23 sierpnia 2007 r. o przeciwdziałaniu nieuczciwym praktykom rynkowym, t.j. z dnia 9.11.2017 r., Dz.U. 2070 z 2017 r.

[www 1] Nowy tad konsumencki, www. ec.europa.eu 9 (30.04.2018)

[www 2] Dekada wolnego rynku energii - co się zmieniło?, 27.11.2017 r., www. wysokienapiecie.pl (30.04.2018).

[www 3] Second consumer market study on the functioning of the retail electricity markets for consumers in the EU Final report 2016, www.europa.eu (18.05.2018).

Zdyb M., Sieradzka M. (eds), 2016, Komentarz Ustawa o zwalczaniu nieuczciwej konkurencji, Wolters Kluwer, Warszawa.

\section{ŹRÓDŁA INFORMACJI WPLYWAJĄCE NA ZACHOWANIA KONSUMENTÓW NA RYNKU ENERGII ELEKTRYCZNEJ}

Streszczenie: Energia elektryczna jest czynnikiem ułatwiającym funkcjonowanie konsumentów w społeczeństwie oraz stwarza odpowiednie warunki do pracy, rozwoju i odpoczynku. Konsumenci na rynku energii elektrycznej ze względu na skalę i tempo zmian, będących efektem dokonującego się postępu i nowych regulacji, nie mają odpowiedniej wiedzy zarówno technicznej, jak i ekonomicznej oraz prawnej. Do jednych z największych problemów rynku energii elektrycznej w Polsce należy zaliczyć wysoki poziom braku znajomości usług, instytucji i podstawowych pojęć, potrzebnych do podejmowania racjonalnych decyzji na rynku energii elektrycznej. Konieczne jest określenie, z jakich źródeł konsumenci czerpią wiedzę na temat rynku energii elektrycznej. Na podstawie przeprowadzonych przez autorkę badań można stwierdzić, że wiedza i umiejętności dotyczące oceny rynku energii elektrycznej, instytucji na nim działających oraz ich oferty rynkowej jest bardzo niewielka.

Słowa kluczowe: zachowania konsumentów na rynku energii elektrycznej, energia elektryczna, konsumenci. 